\title{
The Larval Stages of Longipedia coronata Claus, L. scotti G. 0. Sars, and L. minor T. and A. Scott, with a Description of the Male of $L$. scotti.
}

\author{
By
}

A. G. Nicholls,

Assistant Naturalist at the Marine Station, Millport.

With 8 Figures in the Text.

Contents.

Introduction

The Nauplii of L. coronata

The Antennule.

The Antenna

The Mandible .

The Maxillule .

Other Appendages

The Caudal Region

The Nauplii of $L$. scotti

The Nauplii of L. minor .

The Copepodite Stages of Longipedia

A Comparison with the Cirripedes

Breeding and Development

Feeding in Longipedia

The Male of Longipedia scotti .

Summary

References

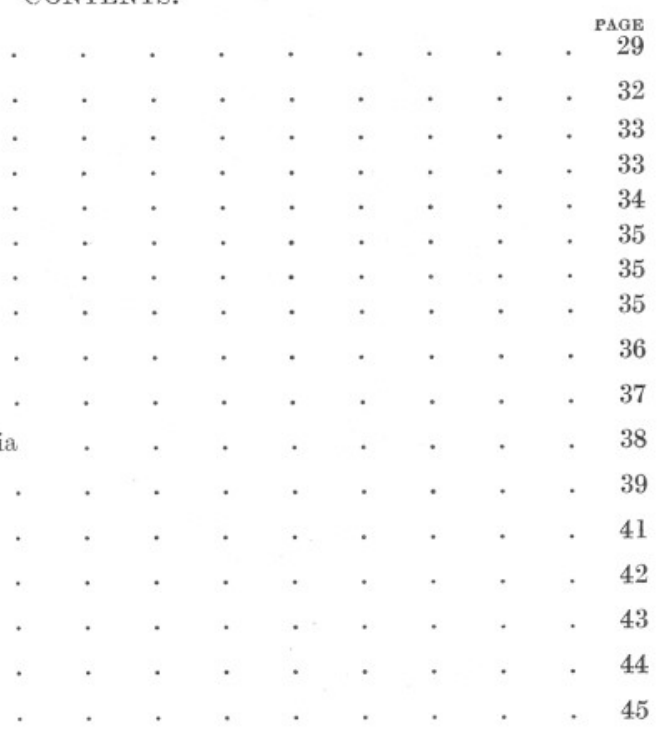

INTRODUCTION.

DURING the course of some routine plankton work over the years 1931-33, embracing collections from various parts of the Clyde sea-area, nauplii of a peculiar appearance were noticed and many were removed for further examination. In this way over 300 specimens were secured, which on measurement showed five clear size groups, corresponding to five different stages. This nauplius was identified as one of the Longipediidæ (Copepoda), described and illustrated by Gurney (1930, p. 469) as "Genus III." Hauls in Loch Striven in 1934 showed large numbers of this nauplius 
early in April, and many were isolated alive in an endeavour to rear them and so trace their origin. As pointed out by Gurney they are very easily caught on the surface film, which makes them difficult to rear in open vessels. By placing them under a system of water circulation from which all air was excluded it has been possible to rear them to the first copepodite stage. The later copepodites are easily reared in small open dishes containing a little mud, covered with about 10 c.c. of water. Nauplii

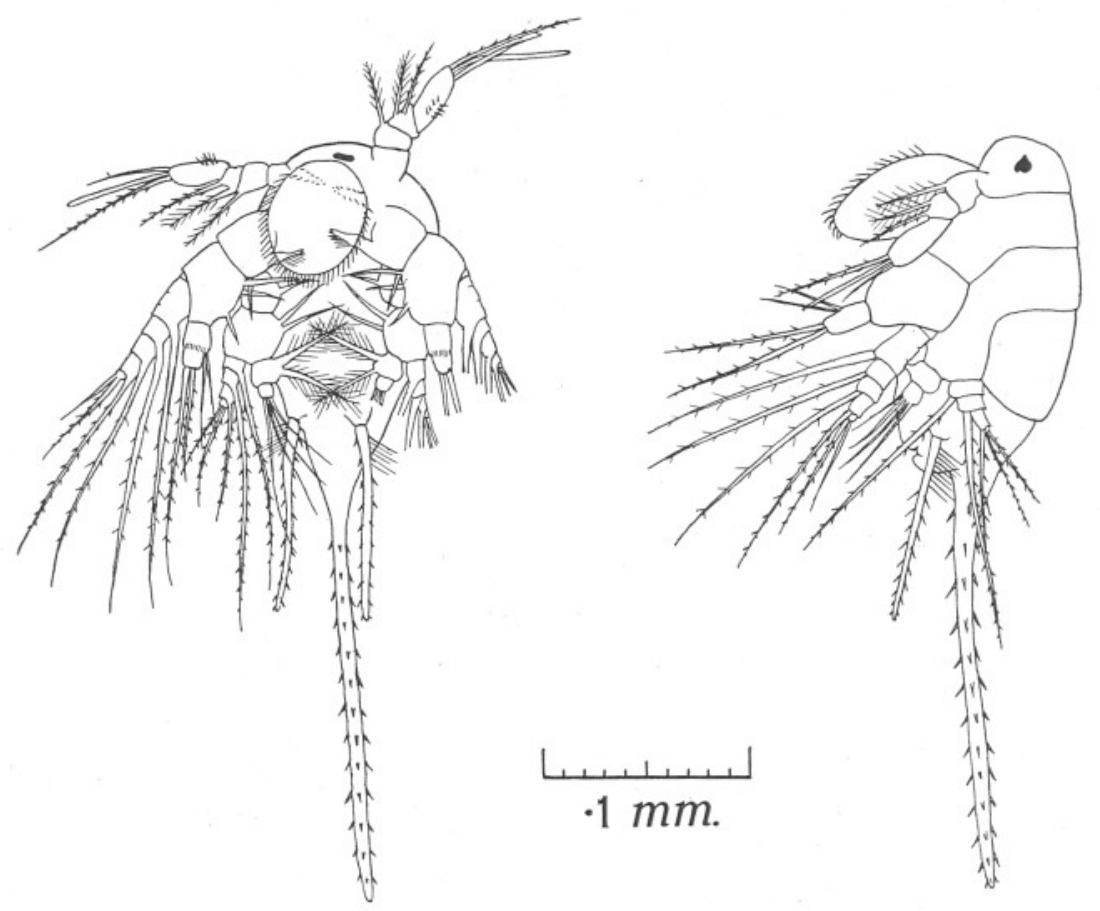

FIG. 1.-The first nauplius of $L$. coronata from below and from the left side. The specimen illustrated was peculiar in showing the three primary segments of the head region, corresponding to the first three nauplius appendages. No other specimen was seen showing this structure which must not be regarded as normal for the first nauplius of this species.

have also been successfully reared in open glass tubes, $6^{\prime \prime} \times 1^{\prime \prime}$, which provide a sufficient depth of water to reduce the chances of their becoming caught in the surface film. At the second copepodite stage the animal is definitely recognisable as a Longipedia by the elongated endopod of the second leg (see also Gurney, 1930, p. 467). The larva has been reared through all its stages of development and identified as that of Longipedia coronata.

Ovigerous females of this species were obtained by using a bottom net; and on hatching the eggs, the first nauplius, not previously seen in plankton 

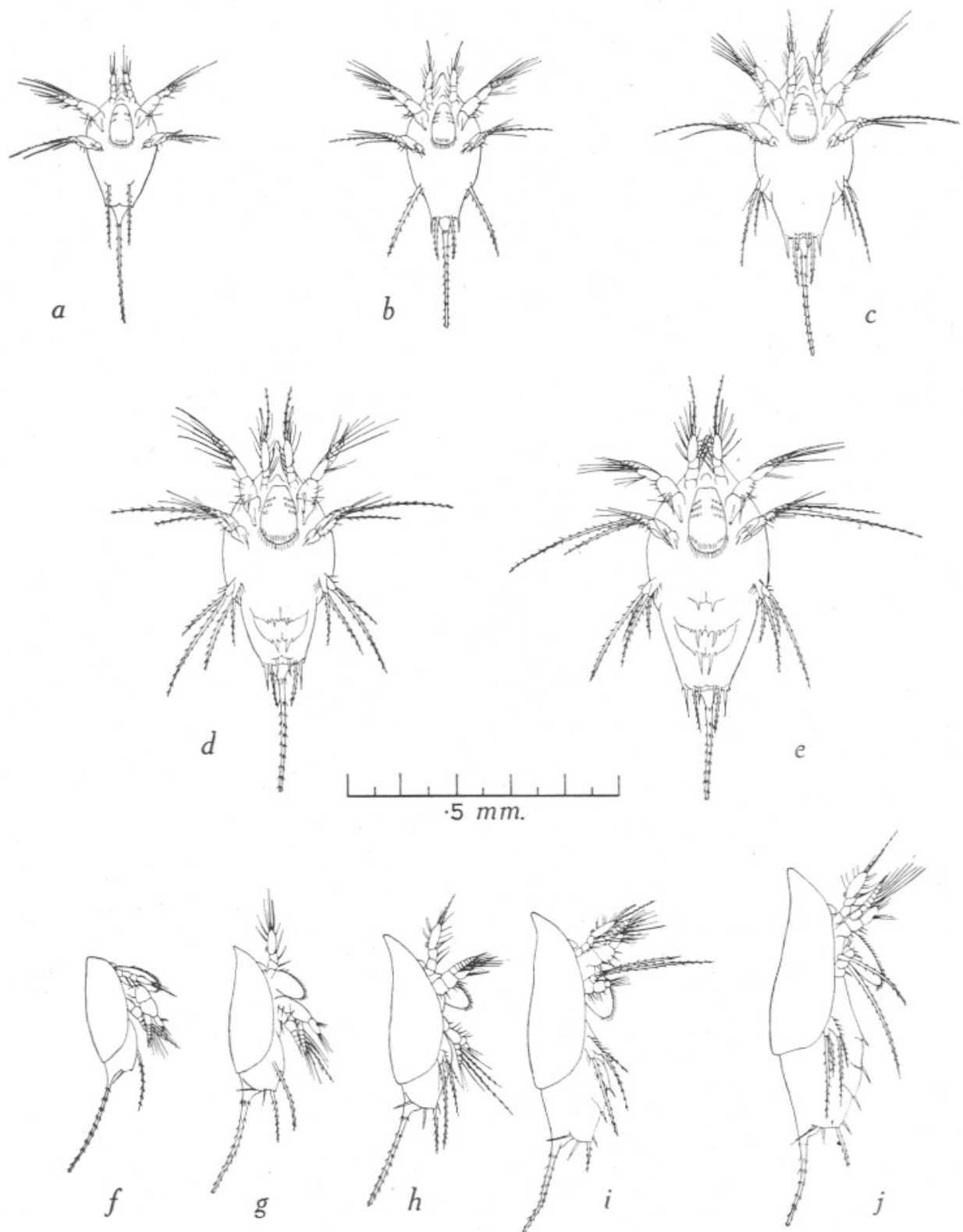

Frg. 2.-The second to sixth nauplii of $L$. coronata ; $a$ to $e$, in ventral view ; $f$ to $j$, in lateral view. 
samples, has been found. This has proved interesting in that it resembles in shape the Longipedia nauplius described by Gurney (1930, p. 463) as the " green form." There is no anterior projection of the head region and this seems to be typical of the genus, modification in shape occurring only in later stages.

In the search for the adult of $L$. coronata, specimens of $L$. scotti (not previously recorded from this area) were obtained and these, when their eggs were hatched, proved to have a first nauplius indistinguishable, even in size, from that of $L$. coronata. In the later nauplii, however, the posterior terminal spine shortens and the larva assumes the form of that described by Gurney (1930, p. 464, Fig. 2) as the " pink form." All the
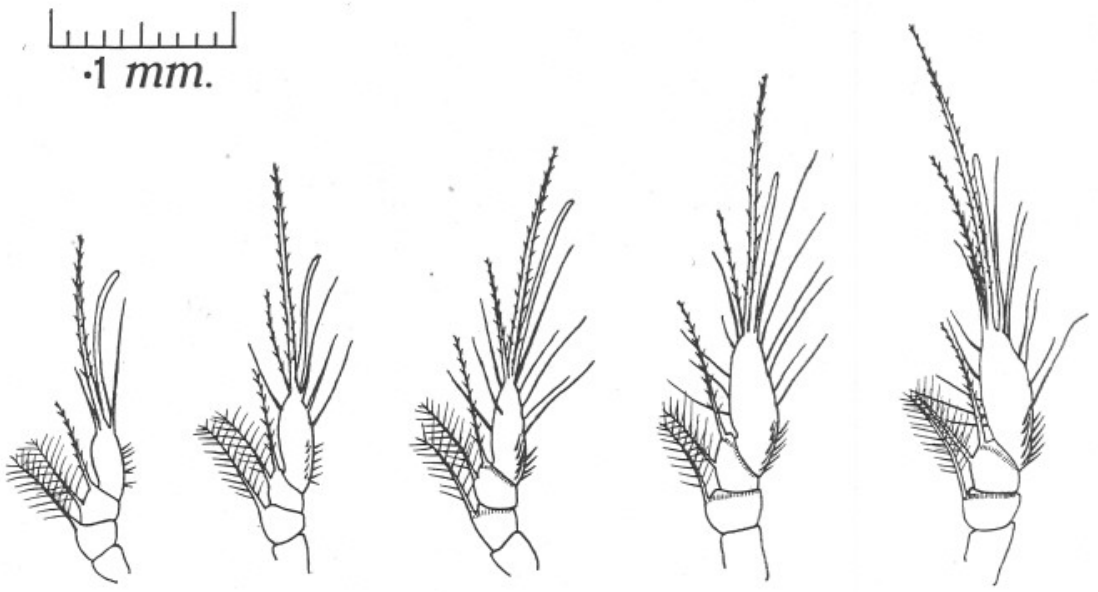

FIG. 3.-The antennules of nauplii two to six of $L$. coronata.

nauplius stages of this form also have been reared and since it is less liable to be held in the surface film its rearing does not present the same difficulty.

The nauplii of $L$. coronata are illustrated in full. The structure of the appendages differs in only minor details from that of the "green form" described by Gurney.

\section{The NaupliI of L. coronata.}

The nauplius was first described and figured by Gurney (1930) and is peculiar "in the long narrow shape of the body and remarkable helmetshaped head. Not only is the head produced forwards and upwards but it has also a downward beak-like projection" (p. 469). These features can be seen in Figure 2 and the very prominent labrum, covered with small spines and fine hairs, will be noticed. An eye is visible in fresh material. 


\section{The Antennule (Figs. 1 and 3).}

This has four segments, the first being unarmed; the second bears one plumose seta; the third, one plumose and one spinous seta. The armature of these three segments is constant throughout the six nauplii. The terminal segment is elongated and bears one spinous seta and an æsthetasc terminally, with a number of subsidiary terminal and lateral setæ varying from one in the first nauplius to fourteen in the sixth. A double row of short bristles is present on the outer edge of this segment, the number increasing from first to last nauplius. The changes that take place in this appendage are seen in Table $\mathrm{I}$.

\section{TABLE I.}

\section{Segmentation and Armature of Antennule.}

"A" indicates Esthetasc.

$\begin{array}{ccccccc}\text { Segment. } & \text { I } & \text { II } & \text { III } & \text { IV } & \text { V } & \text { VI } \\ 1 & - & - & - & - & - & - \\ 2 & 1 & 1 & 1 & 1 & 1 & 1 \\ 3 & 2 & 2 & 2 & 2 & 2 & 2 \\ 4 & 2+\mathrm{A} & 3+\mathrm{A} & 6+\mathrm{A} & 10+\mathrm{A} & 13+\mathrm{A} & 15+\mathrm{A}\end{array}$

The Antenna (Figs. 1 and 4).

The coxopodite and basipodite are armed with strong masticatory spines and setæ; the unsegmented endopodite has rigid spinous terminal setæ and a group of lateral setæ on the inner edge; the exopodite is long and well developed with many segments, five in the first nauplius, increasing by one segment with each moult to the maximum of eight in the fourth, fifth and sixth nauplii (Table II).

\section{TABLE II.}

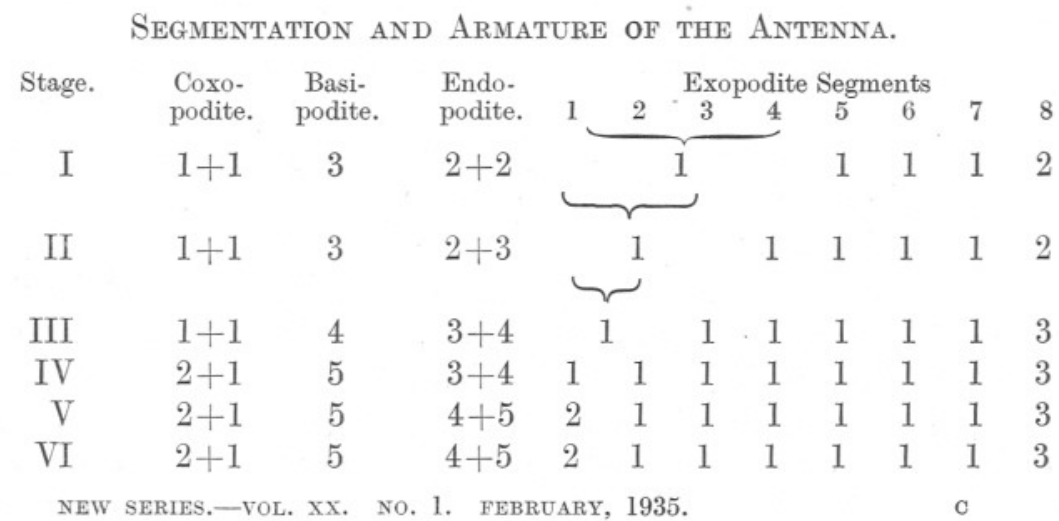


There is no further development of the number of setæ from the fifth to the sixth nauplius but the large masticatory spine on the coxopodite is considerably enlarged at this moult.
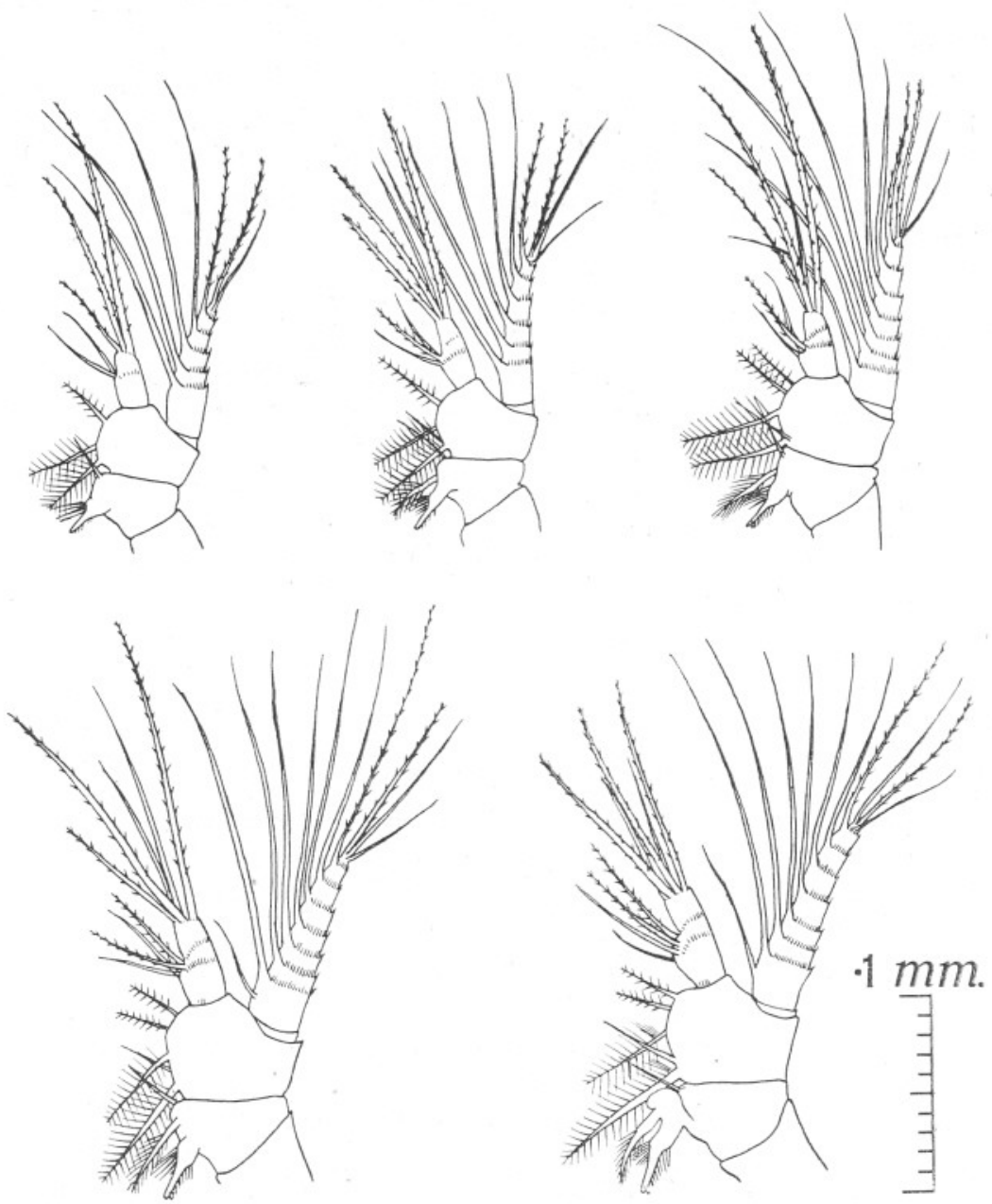

FIg. 4.-The antennæ of nauplii two to six of $L$. coronata.

The Mandible (Figs. 1 and 5).

There is a very small coxopodite bearing a single plumose seta. The basipodite is more strongly armed with a number of plumose setæ but the main armature of this masticatory appendage is the powerful spine on the enlarged first segment of the endopodite, which has in addition a number of plumose setæ. The terminal segment of the endopodite bears a group 
of unplumed setæ. The exopodite is four-segmented in all stages and bears rigid spinous setæ, two of which are particularly long and strong. The changes in this appendage are summarised in Table III.

\section{TABLE III.}

Segmentation and Armature of the Mandible.

\begin{tabular}{rcccccccc} 
Stage. & Coxo- & Basi- & \multicolumn{2}{c}{ Endopodite } & \multicolumn{3}{c}{ Exopodite. } \\
podite. & podite. & 1 & 2 & 1 & 2 & 3 & 4 \\
I & 1 & 2 & $1+1$ & 4 & 1 & 1 & 1 & 2 \\
II & 1 & 3 & $3+1$ & 5 & 2 & 1 & 1 & 2 \\
III & 1 & 4 & $3+1$ & 6 & 2 & 1 & 1 & 2 \\
IV & 1 & 7 & $4+1$ & 6 & 2 & 1 & 1 & 2 \\
V & 1 & 7 & $4+1$ & 6 & 2 & 1 & 1 & 2 \\
VI & 1 & 8 & $4+1$ & 6 & 2 & 1 & 1 & 2
\end{tabular}

The Maxillule (Figs. 2 and 6).

This appendage is represented in the first three nauplii by a single large spine, thickly covered with small spines and in the first nauplius bearing a number of fine hairs at the base. These hairs are lacking in the second and third nauplii. In subsequent stages a two-segmented appendage is present bearing large terminal spines and small lateral setæ (Table IV).

\section{TABLE IV.}

Segmentation and Armature of the Maxillule

\begin{tabular}{|c|c|c|c|c|c|c|}
\hline \multirow[t]{2}{*}{ Segment } & \multicolumn{6}{|c|}{ Nauplius Stage } \\
\hline & I & II & III & IV & V & VI \\
\hline Sndonodite & & & oine & $2+3$ & $2+6$ & $2+6$ \\
\hline Exo & & & & $2+1$ & $2+3$ & $2+3$ \\
\hline
\end{tabular}

Other Appendages (Fig. 2).

The first two pairs of swimming feet present in the first copepodite are represented in the fifth and sixth nauplii as " ridges with spines, but are not definitely bilobed "(Gurney, 1930, p. 466). The maxillæ and maxillipeds are situated just behind the maxillules but are not clearly separable in L. coronata.

The Caudal Region.

A pair of short, backwardly directed setæ first appear in the second nauplius in the region of the anus. To these are added in the third nauplius one pair of short setæ, upwardly directed and situated dorsal to the first pair, and a second pair of long, spinous setæ postero-ventrally (Fig. 2, $f-j)$. In the fourth nauplius one pair of short spines appears just 
anterior to the postero-ventral pair. The single median posterior spine, most prominent of all, is present in all stages, and characteristic of the nauplii of the genus. The arrangement of spinules upon this spine appears to be spiral.

The NAUplin of L. scotti.

The "pink form " of Gurney undoubtedly belongs to this species and nauplii reared from females with egg-sacs have been carried through to

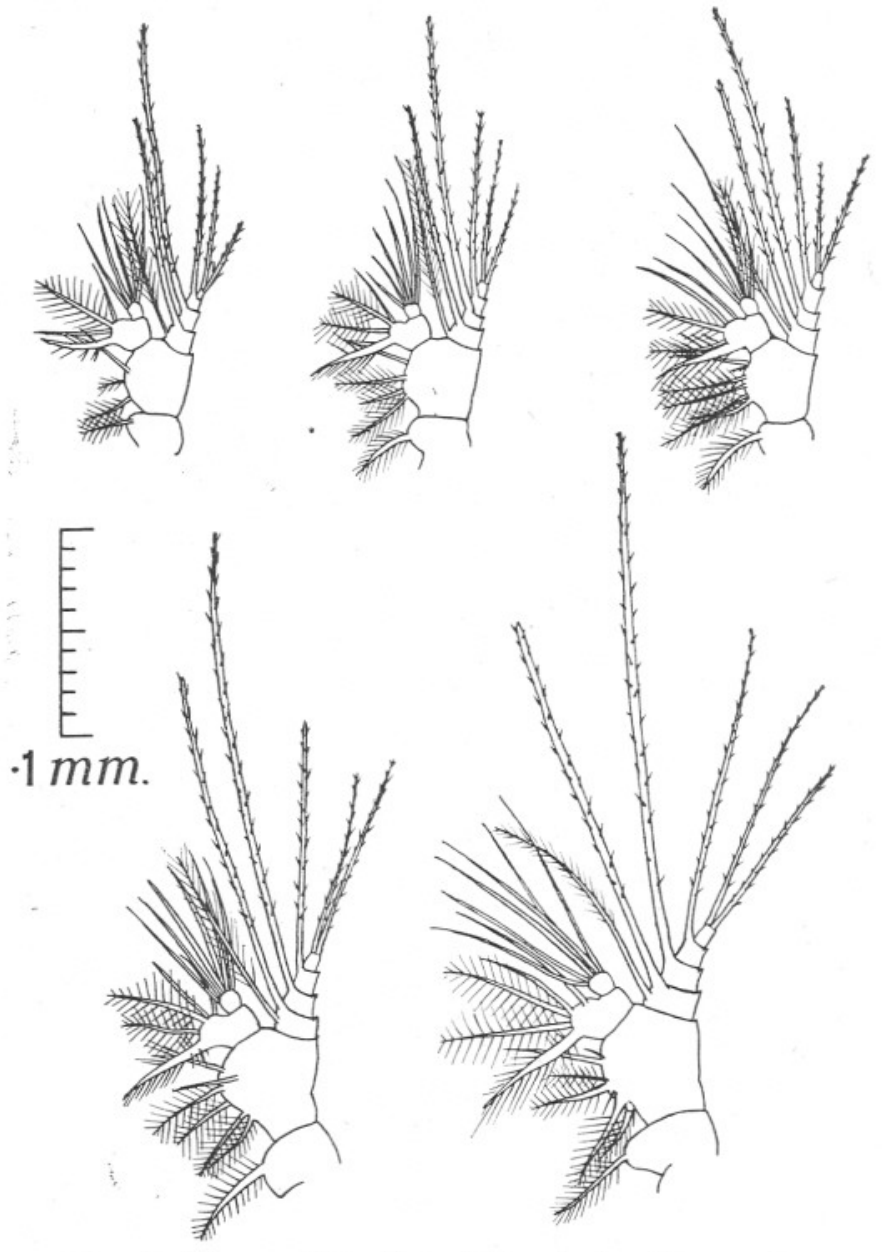

FIG. 5.-The mandibles of nauplii two to six of $L$. coronata.

the fifth copepodite, while later nauplii collected from the plankton have been reared to the adult stage. The male has thus been obtained and will be described later (p. 43). 
Again six nauplius stages are present, the first indistinguishable from that of $L$. coronata, the later stages showing the modification of shape peculiar to this species-namely, the broad, rounded anterior; the square labrum; the shortening of the posterior spine; and the presence of a tooth on the basipodite of the antenna. The patchy coloration which develops in the later nauplii is also distinctive.

Apart from these features, mentioned by Gurney (1930, p. 467) the exopodite of the maxillule shows a structure different from that of the preceding species. The exopod in $L$. coronata bears one rigid spine and a
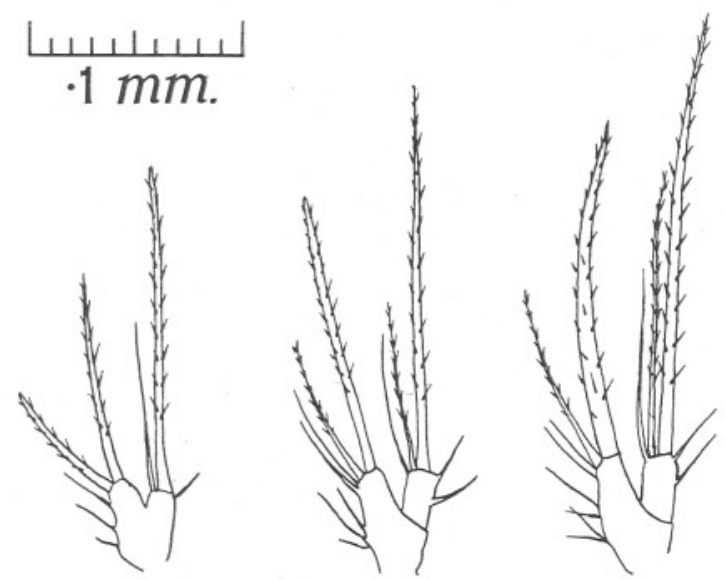

FIG. 6.-The maxillules of nauplii four to six of $L$. coronata.

number of shorter setæ, whereas in $L$. scott $i$ the rigid spine is replaced by a group of setæ of sub-equal length (see Gurney, 1930, Fig. 2). The tooth on the basipodite of the antenna first appears in the second nauplius. For the rest, the appendages resemble those figured and described for L. coronata.

\section{The NaupliI of L. minor.}

One specimen of a small yellow nauplius in the fifth stage was obtained from the plankton. This moulted through successfully to become an adult female, quite clearly L. minor. An examination of the moults of this nauplius showed that it was identical in structure with the " green form " of Gurney. The apparent discrepancy here with Gurney's colour description is, I think, easily explained. The depth of pigmentation varies in different individual nauplii of a species, and when the natural coloration is absent or greatly reduced, the yellow colour of the food mass predominates, leading one to ascribe that colour to the nauplius as a whole in the absence of any other. Nauplii of both L. coronata and L. scotti have been obtained in which the usual red or pink colour has been absent, and 
the only colour noticeable has been the greenish yellow of the gut contents. Gurney described the green form and stated that the yellow form was "very rare by comparison." It so happens that the single specimen of this species obtained here lacked the green pigmentation and so appeared to be yellow.

The maxillule in this nauplius is of the $L$. scotti type. A point of interest is that in the sixth nauplius of this species the maxilla and maxilliped are much more clearly separated than in either of the preceding species. One further point should be noticed, namely that there are four segments in the antennule in all three species, the proximal one being unarmed throughout.

\section{Average Lengths of the NaUplit in ma.}

\begin{tabular}{|c|c|c|c|c|c|c|c|c|c|c|c|c|}
\hline $\begin{array}{l}\text { Nau- } \\
\text { plius }\end{array}$ & & L. cor & onata. & & & L. & cotti. & & & L. m & inor.* & \\
\hline Stage. & Body & Spine & Total & $\mathrm{S} / \mathrm{T}$ & Body & Spine & Total & $\mathrm{S} / \mathrm{T}$ & Body & Spine & Total & $\mathrm{S} / \mathrm{T}$ \\
\hline I & $\cdot 15$ & $\cdot 19$ & $\cdot 34$ & $\cdot 6$ & $\cdot 15$ & $\cdot 15$ & $\cdot 30$ & $\cdot 5$ & $\cdot 13$ & $\cdot 14$ & $\cdot 27$ & .5 \\
\hline II & $\cdot 20$ & $\cdot 22$ & $\cdot 42$ & .5 & $\cdot 19$ & $\cdot 11$ & $\cdot 30$ & $\cdot 4$ & $\cdot 18$ & $\cdot 17$ & $\cdot 35$ & $\cdot 5$ \\
\hline III & $\cdot 26$ & .21 & .47 & $\cdot 4$ & $\cdot 24$ & .06 & $\cdot 30$ & $\cdot 2$ & $\cdot 19$ & $\cdot 18$ & $\cdot 37$ & $\cdot 5$ \\
\hline IV & $\cdot 33$ & $\cdot 20$ & .53 & $\cdot 4$ & $\cdot 27$ & .07 & $\cdot 34$ & $\cdot 2$ & $\cdot 22$ & $\cdot 19$ & .41 & $\cdot 5$ \\
\hline V & .40 & $\cdot 16$ & .56 & $\cdot 3$ & .32 & $\cdot 10$ & $\cdot 42$ & $\cdot 2$ & $\cdot 27$ & $\cdot 18$ & .45 & .4 \\
\hline VI & $\cdot 45$ & $\cdot 21$ & $\cdot 66$ & $\cdot 3$ & $\cdot 37$ & .08 & .45 & $\cdot 2$ & $\cdot 30$ & $\cdot 18$ & $\cdot 48$ & $\cdot 4$ \\
\hline
\end{tabular}

This table gives the lengths of the body and of the spine, and the ratio spine to total length $(\mathrm{S} / \mathrm{T})$, for all stages of the three species under discussion. It is interesting to see that in $L$. coronala, while the body shows a steady increase in length, the spine remains more or less constant and, therefore, grows relatively shorter. In $L$. scotti while the body grows in length the spine shortens considerably, giving a marked relative decrease. In $L$. minor the spine shows an increase in length as the body grows, thus showing very little relative shortening.

\section{The Copepodite Stages of Longipedia.}

The early copepodite stages of Longipedia, showing the development of the second leg, have been described and illustrated by Gurney (1930), and it will suffice here to give a summary in tabular form of the number of segments and swimming legs present in each stage. In the table below, a segment bearing no appendages is indicated by " $\times$ " ; " $\mathrm{r}$ " indicates that the limb is rudimentary; " $\mathrm{f}$ " stands for the caudal furcæ.

Though some authors (Claus, 1863 ; Sars, 1911; Wilson, 1932) have stated that the long endopod of the second leg may be used in locomotion, and though it might reasonably appear to be useful on muddy grounds such as Longipedia inhabits, yet during four months constant observation

* Lengths of the first four stages are taken from Gurney (1930); those of the fifth and sixth nauplii are lengths of moults of the single specimen obtained here and agree exactly with Gurney's measurements for these stages. 
of the living animal, kept on mud, I have never seen the endopods used in the manner suggested by Sars. Normally the animal remains buried beneath the surface of the mud, through which it burrows vigorously, and if disturbed it swims actively about on its side or back, the endopods of the second legs taking no part in the swimming but remaining folded back along the body.

\begin{tabular}{|c|c|c|c|c|c|c|c|c|c|c|}
\hline $\begin{array}{l}\text { Cope- } \\
\text { podite }\end{array}$ & & & & egmen & $s$ of $B$ & & & & & \\
\hline Stage. & Cephalosome & 2 & 3 & 4 & 5 & 6 & 7 & 8 & 9 & 10 \\
\hline I & pl & p2 & p3r & $x$ & $\times f$ & & & & & \\
\hline II & pl & p2 & p3 & $\mathrm{p} 4 \mathrm{r}$ & $\times$ & $\times f$ & & & & \\
\hline III & $\mathrm{pl}$ & p2 & p3 & $\mathrm{p} 4$ & p5r & $\times$ & $\times f$ & & & \\
\hline $\begin{array}{r}\text { IV } 0 \\
0 \\
\phi\end{array}$ & p1 & p2 & p3 & $\mathrm{p} 4$ & p5 & $\begin{array}{l}\mathrm{p} 6 \mathrm{r} \\
\times\end{array}$ & $\times$ & $\times f$ & & \\
\hline $\begin{array}{r}\mathrm{V}_{3} \\
\text { क्+ }\end{array}$ & p1 & p2 & p3 & $\mathrm{p} 4$ & p5 & $\begin{array}{l}\mathrm{p} 6 \\
\times\end{array}$ & $x$ & $x$ & $\times f$ & \\
\hline $\begin{array}{r}\mathrm{VI}_{0} \\
\text { 우 }\end{array}$ & $\mathrm{p} 1$ & p2 & p3 & $\mathrm{p} 4$ & p5 & $\begin{array}{l}\mathrm{p} 6 \\
\times\end{array}$ & $x$ & $x$ & $x$ & $\times f$ \\
\hline
\end{tabular}

\section{A Comparison with the CirRIPedes.}

Gurney (1931, p. 80) points out that Hansen in 1899 described the nauplius of Longipedia as that of an unknown copepod. He in turn refers to the earlier work of Claus (1863) who also recognised this larva as that of a copepod. All of these workers have remarked on the resemblance between this nauplius and that of the cirripede, and the relationship of the family Longipediidæ has been fully discussed by Gurney (1930, p. 472). There are one or two points of interest that have arisen which seem to stress the possible relation between Longipedia and the cirripedes.

While the general shape of the body of the nauplius seen from the dorsal view resembles that of a Calanoid (Gurney, 1930, p. 472), yet the later nauplii of $L$. scotti bear a striking resemblance to that of a cirripede when viewed from the side (see Fig. 7, $d$ and $e$ ). A comparison of the appendages in Figures $3-5$ with those of the cirripede (Groom, 1894) brings out other points of similarity in addition to those referred to by Gurney (1930), in particular the structure of the masticatory spine on the coxopodite of the antenna. Moreover the nauplii of Longipedia with four segments in the antennule occupy a position intermediate between those of the majority of copepods with three segments and those of the cirripedes with five.

Another point of considerable interest is the resemblance in the mode of swimming. Calanoid nauplii have a smooth, apparently effortless type of progression, whereas cirripede nauplii move in a laboured, jerky manner, performing circles on their backs. This exactly describes the swimming of 
Longipedia nauplii. It may, of course, be only a mechanical effect due to the long posterior spine present in both. Harpacticoid nauplii are not normally pelagic and so cannot be compared, but if this apparent relation to the cirripedes is real it would strengthen the suggestion made by
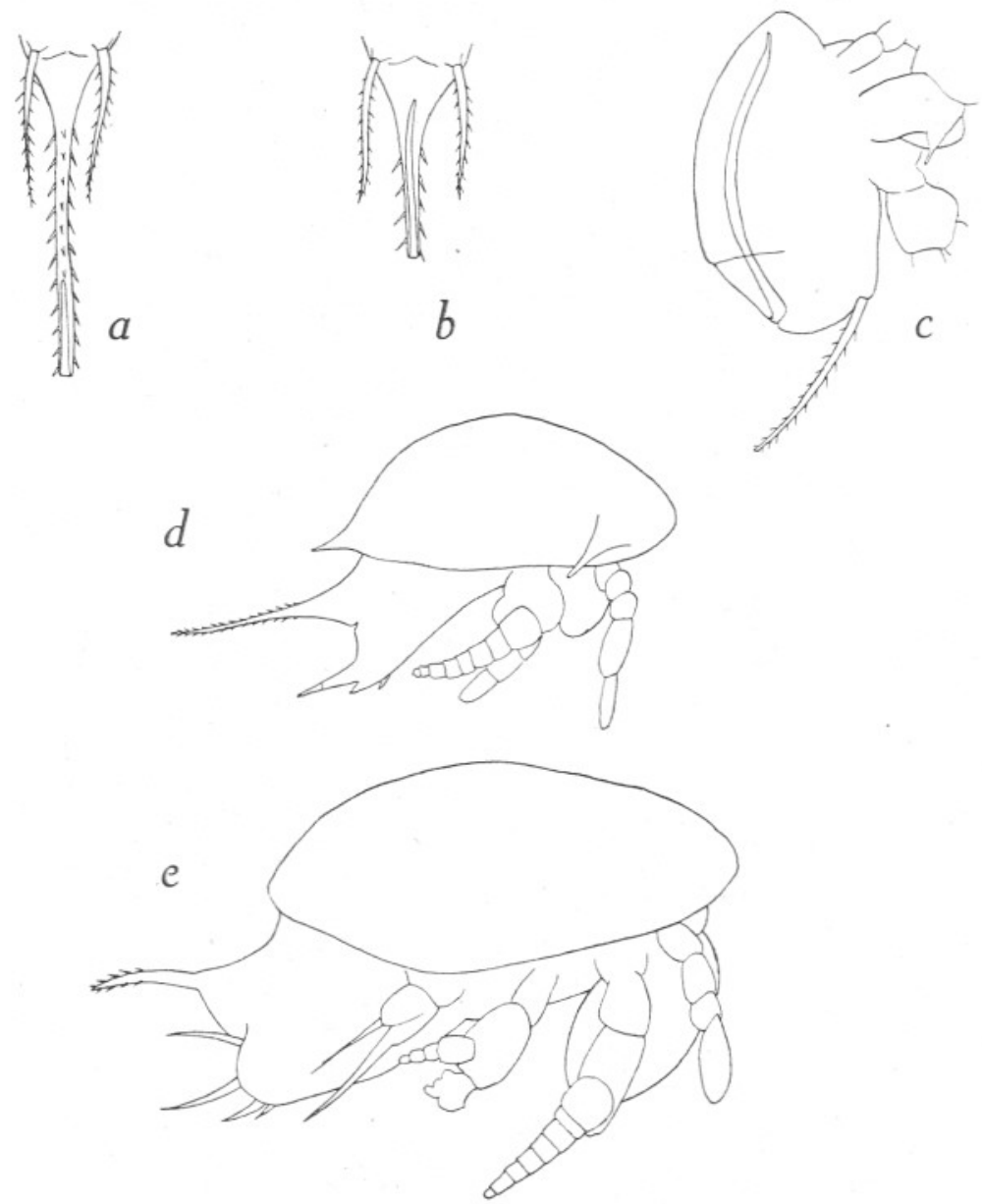

FIG. 7.- $a, b$ and $c$, different stages of invagination of the posterior median spine of Longipedia nauplii. In $c$ it is totally within the body. $d$ and $e$ are nauplii of a cirripede from the plankton and $L$. scott $i$ respectively, drawn from the side to show similarity in shape.

Gurney (1930), from other considerations, that the pelagic state of the nauplii of Longipedia is primitive.

A minor point of similarity is that in the first nauplius of the cirripede Lepas anatifera (Groom, 1894, p. 167, Fig. 153a) the caudal spine is invaginated within the body. Numerous individuals of Longipedia 
nauplii have hatched with the spine partly invaginated (Fig. 7, $a$ and $b$ ) and one whole batch of $L$. scotti nauplii hatched apparently without tail spines. Closer examination showed that the spines were entirely invaginated within the bodies of the nauplii (Fig. 7,c). This is apparently the normal condition in the developing eggs and in this case the spines had failed to be evaginated at the time of hatching. None of this brood of nauplii lived to become second nauplii. This state of invagination in spines during development is not, however, restricted to these two groups.

\section{Breeding and Development.}

It appears that having once received a spermatophore the female produces consecutive broods of eggs for the rest of the breeding season. Active breeding had certainly begun by the beginning of April (large numbers of nauplii and first and second copepodites were taken in the plankton on 6.4.34) and continued (in the laboratory) until the beginning of August. Nauplii were taken occasionally earlier in the year from Keppel Pier and the routine hauls in Loch Striven in 1933 showed them to be present in January. No breeding females lived beyond the beginning of August, but before death one specimen of $L$. scotti had produced at least nine batches of eggs. (It is, of course, impossible to say how many broods it had produced before capture.) An egg-sac was present when the specimen was caught on April 15th; the nauplii hatched within two days and four more broods had appeared by the beginning of June, at intervals of five or six days and taking on the average as many days to develop. After a rest of 15 days breeding began again and three more broods appeared. A further rest of 10 days was followed by the production of the ninth egg-sac, the nauplii taking six days to hatch. A few days later this female died an apparently natural death.

About 14-20 nauplii hatched from each egg-sac in the early part of the year, but of the fourth and fifth broods only one hatched from each, and it appeared that the supply of spermatozoa might have been exhausted. The sixth egg-sac, however, produced 11 nauplii and the seventh two or three, but no nauplii were seen from either of the last two broods.

A specimen of $L$. coronata produced seven batches of eggs between April 18th and July 4th after which it died. In the case of this specimen there was clear evidence of a speeding up of reproduction as the summer advanced and the (laboratory) temperature rose. The first three broods took on the average nine days to develop with four-day intervals. A thirteen-day interval followed and then a fourth brood appeared. The remaining three broods took an average of six days to develop, with one-day intervals.

There is no evidence of parthenogenesis in Longipedia such as has been 
recorded in Canthocamptus (Gurney, 1932, p. 109). A specimen of $L$. coronata reared from the second copepodite lived for 44 days as an adult female, with one ovary developed, but no eggs were spawned ; similarly the specimen of $L$. minor reared from the fifth nauplius lived as an adult female for a similar period with well developed ovaries, but did not spawn.

Three nauplii of $L$. coronata hatched on June 8th became first copepodites on 21st and 22nd of that month, having taken 13-14 days and one of a batch of $L$. scotti nauplii, hatched on May 28th, became a first copepodite on June 14th, taking 17 days. The time taken in development varies, of course, with temperature and abundance of food and these figures, therefore, cannot be regarded as more than an indication of the normal time. At first, copepodites were kept on muddy sand similar to that of their natural habitat; no food was added and development proceeded slowly. Later, diatoms were added and the rate increased. Three different specimens took 27, 21 and 33 days to develop from first to sixth copepodites (May to July).

\section{Feeding in Longipedia.}

An adult female of $L$. scotti and a specimen of $L$. minor while a third copepodite, were observed feeding on diatoms. The process was the same in both cases. The mouth parts normally are in a state of constant vibration, the antennules and antennæ not taking part in the vibration. The animal feeds while lying on its side or back and the current caused by the vibration of the mouth parts brings diatoms, detritus, etc., directly towards the mouth from the sides and front of the animal. The outgoing current passes ventrally along the body between the swimming legs. Diatom chains, and Phæocystis colonies were observed drifting towards the mouth, the former being held by the antennæ and passed in end on. Phæocystis colonies were broken up by the mandibles and as much as possible ingested. A large number of cells was lost and a fine stream of these was observed passing away in the ventral current. Colonies were dealt with one at a time and if a second arrived before one had been broken up, this was held away from the mouth parts by the antennæ and passed on at the right moment. The anterior portion of the gut was thus gradually filled and a fæcal pellet, which meanwhile had been formed from the contents of the posterior portion, was then forcibly expelled. All vibration ceased during this process. Vigorous peristalsis refilled the posterior portion of the gut and feeding proceeded. In a steadily feeding animal pellets were expelled about once an hour and food passed through in about two hours (demonstrated by inducing a specimen to accept some carmine granules). Longipedia when feeding is partially selective. A pellet recently expelled was presented for ingestion, but though broken 
up by the mouth parts none of it was ingested. The carmine was ingested in small quantities with other food.

The Male of Longipedia scotti.

Though four species of Longipedia have been distinguished by Sars in his excellent monograph on the Crustacea of Norway (1911), the male

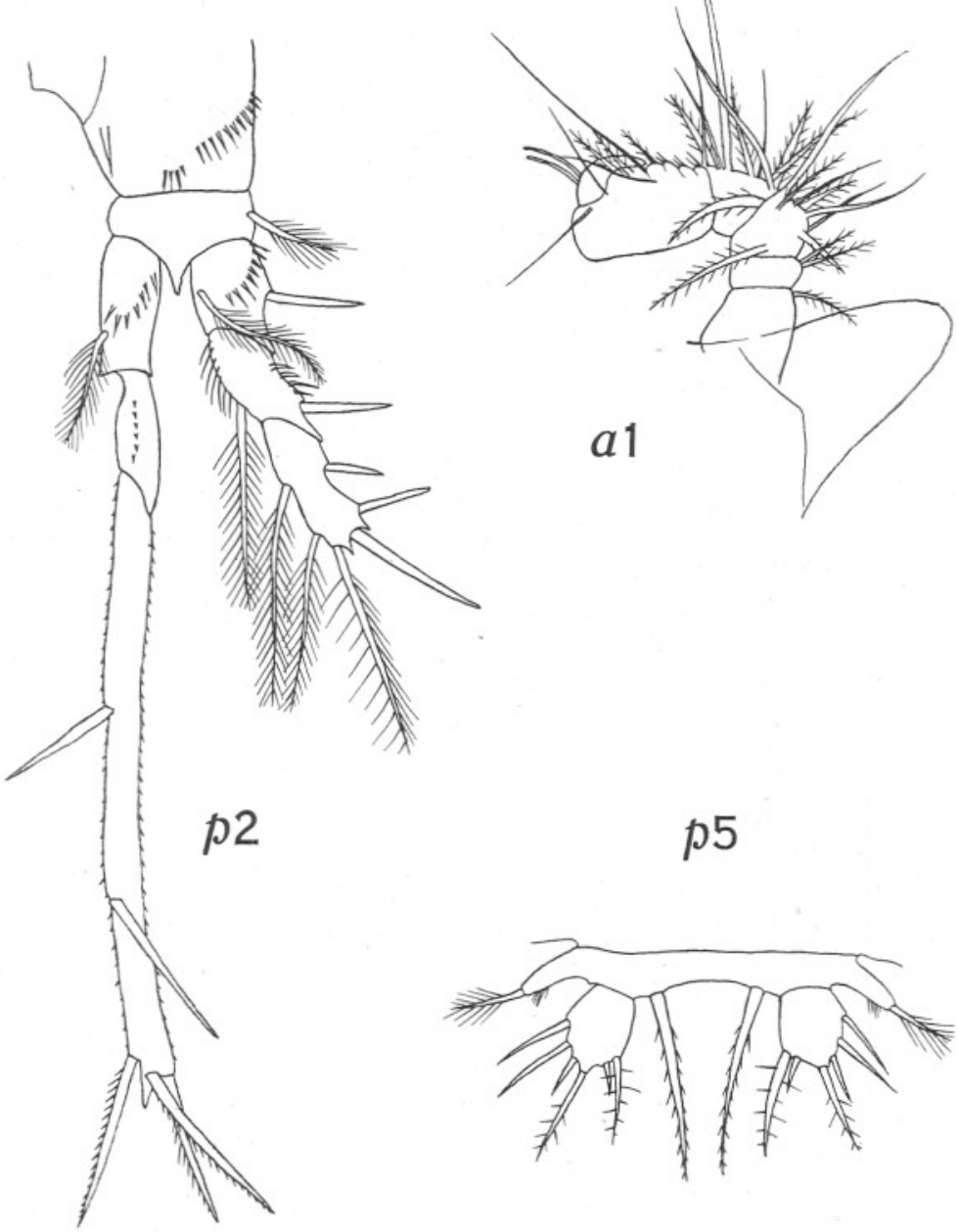

Fig. 8.-The antennule, second and fifth legs of the male of L. scotti.

of only one was included, that of the type species, $L$. coronata. That of L. minor had already been described by T. Scott (1893, p. 200). So far as I am aware the male has not since been described for either of the two 
remaining species. While rearing specimens of this genus a number of males appeared belonging to both $L$. coronata and $L$. scotti, but only one of the latter became adult.

The male is easily recognisable as such in the fourth copepodite stage by the presence of "lappets" on the genital segment. The typical male prehensile antennule is not developed until the adult state is attained.

The male of $L$. scotti is slightly smaller than the female and can be distinguished by the structure of the antennule; by the presence of only two lateral spines on the terminal segment of the endopod of the second leg, in which it differs from all the other forms of Longipedia described by Sars, but resembles the male of $L$. minor (see Scott, 1893); by the fifth legs which show slight differences from those of the female; and by the genital lappets already referred to. The last three segments of the urosome bear fringes of denticles similar to those of the female, but they are more clearly defined ventrally than dorsally. The anal operculum is identical with that of the female (see Sars, Pl. V).

The chief features of the male of this species are illustrated in Figure 8 from the adult of the single specimen which attained maturity in the laboratory. No males of this species and but a single male of $L$. minor have been taken from the sea, and this shows close agreement with Scott's drawings. Apart from its smaller size it is easily distinguished from the male of $L$. scotti, although both have only two spines on the long terminal segment of the endopod of the second leg, since it is the large external spine which is absent in both cases and the remaining two inner spines occupy the same position as in the respective females.

An interesting point is the presence of spinules on the setæ of the caudal furcæ in all the pre-adult stages of both sexes of all three species of Longipedia examined; but these are lost in the last moult. (Only the female of L. minor has been seen in the pre-adult stages.) Sars has shown that spinules on these setæ are present in the adult female of $L$. rosea and form one of the diagnostic characters of this species.

It may also be worth noting that the fringe of denticles on the posterior edge of the segments of the urosome is present not only in the adults of $L$. scotti but also in the pre-adult stages of the male of $L$. coronata.

All the drawings have been made with the aid of a camera lucida.

It is a pleasure to express here my thanks to Dr. R. Gurney for the interest he has shown in the paper and for reading the MS. before publication.

\section{SUMMARY.}

1. The nauplius stages of three species of Longipedia are described, and the segmentation and armature of the appendages of $L$. coronata are given in tabular form. 
2. The main features in the external structure of the copepodite stages are summarised in a table.

3. Additional points of resemblance between the nauplii of Longipedia and the cirripedes are presented.

4. Notes are given on breeding and development under laboratory conditions ; there is no evidence of parthenogenesis.

5. Feeding in the copepodite stage of Longipedia is described.

6. A description is given of the hitherto unknown male form of $L$. scotti.

\section{REFERENCES.}

Claus, C. 1863. Die frei lebenden Copepoden. Leipzig.

Groom, T. T. 1894. On the Early Development of the Cirripedia. Phil. Trans. Roy. Soc., B, Vol. 185, pp. 119-232.

Gurney, R. 1930. The Larval Stages of the Copepod Longipedia. Journ. Mar. Biol. Assoc., N.S., Vol. XVI, pp. 461-474.

- 1931. British Freshwater Copepoda. Vol. I. Ray Society, London. 1932. Idem, Vol. II, idem.

Hansen, H. J. 1899. Die Cladoceren und Cirripeden der PlanktonExpedition. Ergeb. d. Plankt.-Exped. d. Humboldt-Stiftung. Bd. II.

SaRs, G. O. 1911. An Account of the Crustacea of Norway. Vol. V., Copepoda (Harpacticoida). Bergen.

Scotr, T. 1893. Additions to the Fauna of the Firth of Forth. Pt. V., 11th Ann. Rep. Fish. Board Scot. Pt. III.

Wilson, C. B. 1932. Copepods of the Woods Hole Region, Massachusetts. U.S. Nat. Mus., Bull. 158. 
